\title{
SEASONAL VARIATION IN GREYWATER QUALITY FOR A REAL LIFE SYSTEM
}

\author{
Maitreyee M. Tilve \\ Assistant professor, Civil engineering Department, PVPIT, Budhgaon, Maharashtra, India
}

\begin{abstract}
Greywater is a wastewater generated in a house except toilet and kitchen wastewater. It is grossly contaminated but reuse and recycling is possible in water scarcity areas but greywater couldn't use for drinking purpose. To know the quality of greywater in various seasons specific parameters have to be checked i.e. pH, Acidity, Alkalinity, Hardness, Conductivity, Turbidity, BOD and COD according to "Standard Methods for determining water and wastewater quality, 2000". Greywater generation from a house contributes $59 \%$ from bath, basin and shower, and $41 \%$ from laundry wastewater. Characteristics of greywater changes due to the number, age, lifestyle, health status and water usage pattern of occupants. In this paper, seasonal variation in quality of greywater will be shown. Here, greywater is mainly used for toilet flushing and gardening purpose. Greywater should be colorless, odorless and should not be acidic. So to get idea of greywater quality, continuous evaluation and proper maintenance is required.
\end{abstract}

Keywords: Greywater quality, seasonal variation, parameters

\section{INTRODUCTION}

Water is an essential and rare source required for socioeconomic development but fresh water sources are now in declining situation. The consumption of water goes on increasing due to change in mentality of people. In any household level, there are mainly two sources of wastewater is considered i.e. greywater and blackwater. Greywater is originated from various locations i.e. bathroom, laundry, cloth washers, bath tubs and blackwater is generated from toilets. Kitchen wastewater is not considered in greywater due to high organic content that may cause oxygen depletion and can increase microbial activity which is possibly contain food borne pathogens. Untreated greywater should not be useful for toilet flushing as well as for gardening. Untreated greywater can be treated by simple way i.e. if single family is considered then following treatment is necessary to treat greywater i.e. collecting greywater, piping and dispersing. It may include fine/course screening or filtering to remove particulate matter, disinfectants to remove pathogens and last to the storage tank.

Potential health effects also related with greywater treatment. If untreated greywater get stored for more than 8-10 hours, bacteria which are presents in greywater will grow fast that is harmful to human health. Due to long storage of greywater create nuisance of mosquitoes, odor which will face to the nearby areas. Most greywater users do not treat greywater but used for irrigation purpose. Greywater formation totally depends on availability of water, habits of people as well as situated areas i.e. villages, city.

Greywater reuse offers various advantages which will help to save money by water authorities on clean water supplies as well as sewage flow and public water demand of potable water. This helps to reduce the load on wastewater disposal systems. According to United States Environmental Protection Agency, greywater can be used untreated or it can be treated to varying degrees to reduce nutrients and disease causing micro-organisms (Victor G. Nganga et al, 2012).

In summer, winter and rainy season, water usage is considered nearby 50-53 lit/person/day, 60-64 lit/person/day and 70-75 lit/person/day respectively. These values shows water used by occupants in rainy season is more than other seasons.

\section{MATERIALS AND METHODS}

The greywater collected from a single dwelling which is located near Wanlesswadi, Sangli. To check the quality of greywater throughout the seasons, specific parameters were selected i.e. $\mathrm{pH}$, acidity, alkalinity, hardness, conductivity, turbidity, BOD and COD. These parameters were analyzed as given in "Standard Methods for determining water and wastewater quality, 2000". Greywater was taken by using grab sampling method during the period of 9-11am. Greywater was characterized from June to April 2012-2013.

Table 1: Methodology for determining various greywater quality parameters

\begin{tabular}{|l|l|l|l|}
\hline $\begin{array}{l}\text { Sr. } \\
\text { No }\end{array}$ & Parameter & Method & $\begin{array}{l}\text { Instrument/ } \\
\text { Equipment }\end{array}$ \\
\hline 1 & pH & Electrometric & pH meter \\
\hline 2 & Acidity & Titration & - \\
\hline 3 & Alkalinity & Titration & - \\
\hline
\end{tabular}




\begin{tabular}{|l|l|l|l|}
\hline 4 & Hardness & Titration & - \\
\hline 5 & Conductivity & Electrometric & $\begin{array}{l}\text { Conductivity } \\
\text { meter }\end{array}$ \\
\hline 6 & Turbidity & $\begin{array}{l}\text { Turbidity } \\
\text { meter }\end{array}$ & $\begin{array}{l}\text { Turbidity } \\
\text { meter }\end{array}$ \\
\hline 7 & BOD & Electrometric & $\begin{array}{l}\text { BOD } \\
\text { incubator }\end{array}$ \\
\hline 8 & COD & Electrometric & COD digester \\
\hline
\end{tabular}

\section{RESULTS AND DISCUSSIONS}

This study shows quality of greywater but as per seasonal variation i.e. summer, winter and rainy season. Table 2 shows quality of greywater from each component of system.

Table 2: Quality of greywater during summer season (2013)

\begin{tabular}{|c|c|c|c|c|}
\hline \multirow{2}{*}{$\begin{array}{l}\text { Sr } \\
\text { No. }\end{array}$} & \multirow[t]{2}{*}{ Parameters } & \multicolumn{3}{|c|}{ Raw greywater } \\
\hline & & $\begin{array}{c}\text { Summer } \\
(2013)\end{array}$ & $\begin{array}{l}\text { Rainy } \\
\text { (2012) }\end{array}$ & $\begin{array}{l}\text { Winter } \\
(\mathbf{2 0 1 2})\end{array}$ \\
\hline 1 & $\mathrm{pH}$ & 7.57 & 6.99 & 6.96 \\
\hline 2 & $\begin{array}{l}\text { Acidity (as } \\
\mathrm{CaCO}_{3} \text { ) }\end{array}$ & 157.85 & 222.73 & 262.34 \\
\hline 3 & $\begin{array}{l}\text { Alkalinity (as } \\
\mathrm{CaCO}_{3} \text { ) }\end{array}$ & 243.62 & 314.52 & 234.51 \\
\hline 4 & $\begin{array}{l}\text { Hardness (as } \\
\mathrm{CaCO}_{3} \text { ) }\end{array}$ & 440.36 & 408.10 & 410.57 \\
\hline 5 & $\begin{array}{l}\text { Turbidity } \\
\text { (NTU) }\end{array}$ & 134.20 & 104.56 & 142.06 \\
\hline 6 & $\begin{array}{l}\mathrm{COD} \text { (as } \\
\mathrm{CaCO}_{3} \text { ) }\end{array}$ & 434.26 & 383.57 & 431.72 \\
\hline
\end{tabular}

Table 2: show that quality of greywater from a house is improving i.e. $\mathrm{pH}$ values of greywater come closer to neutral range of $\mathrm{pH}$ as well as average values have been shown in the table. Acidity, hardness, turbidity and COD values go on reducing from winter to summer.

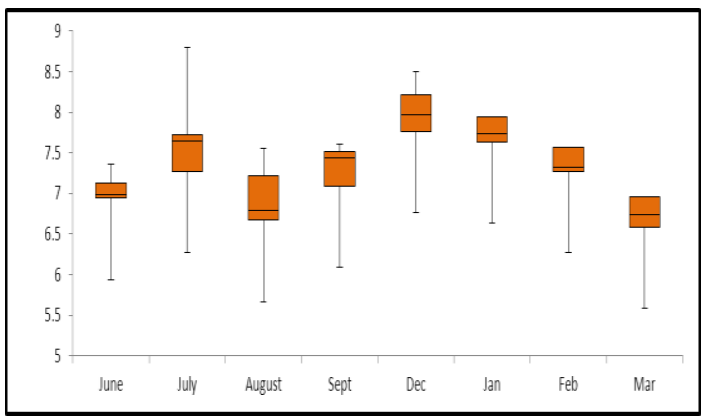

Chart -1: $\mathrm{pH}$ variation throughout a year

$\mathrm{pH}$ values ranging between 5.72-8.3 depends upon the presence of dissolved substances that are coming from bedrock, soils and other materials used in the house.

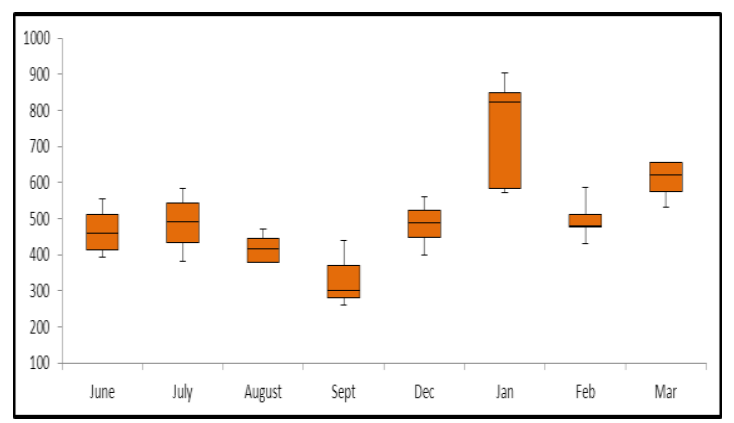

Chart-2: Hardness variation throughout a year

The hardness of a water is governed by the content of calcium and magnesium salts (temporary hardness), largely combined with bicarbonate and carbonates. It is more in January due to more use of water in a house. It ranges from $37-700$ (mg/lit) as $\mathrm{CaCO}_{3}$.

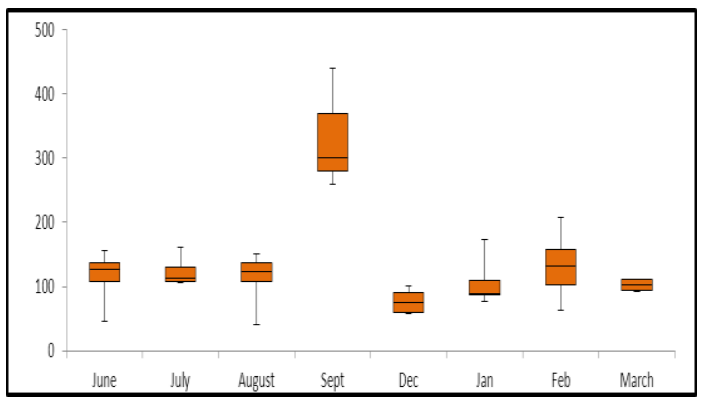

Chart-3: Turbidity variation throughout a year

Due to heavy rainfall, turbidity of greywater in the month of Sept is more and very less in December i.e. ranges from 57 380 NTU.

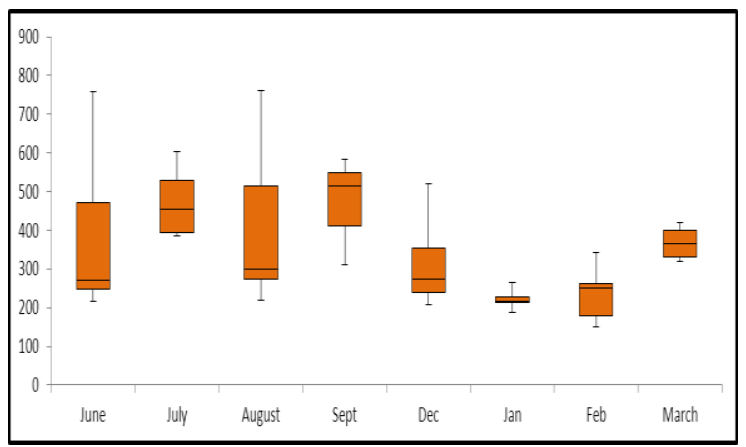

Chart-4: COD variation throughout a year

COD can be related empirically to BOD, organic carbon, or organic matter. Here, in the month of March COD is more than February.

- Introduction

- Materials and methods

- Result and discussions 


\section{CONCLUSIONS}

The results obtained from this paper shows variation in greywater quality throughout a year. Greywater produced in this house having more amount of alkalinity, conductivity and less for $\mathrm{pH}$, hardness turbidity and COD in rainy season when compared with winter and summer season. This shows the quality of greywater in rainy season is better than winter and summer season. Most measured parameters shows seasonal effect with higher values for September and January. This is likely due to the more amount of water used by more/less occupants in a house during September and due to less dilution occurred in greywater during January.

\section{ACKNOWLEDGEMENTS}

I would like to thank my guide Dr. G. R. Munavalli for giving me such a wonderful guidance for my paper publication.

\section{REFERENCES}

[1] Andersen H.R., Lundsbye M., Wedel H.V., Eriksson E. and Ledin A. (2007) "Estrogenic personal care products in a greywater reuse System", Water Science \& Technology Vol 56, No 12, 45-49.

[2] Almqvist Helena and Hanæus Jörgen (2006) "Organic Hazardous Substances in Greywater from Swedish Households". JOURNAL OF ENVIRONMENTAL ENGINEERING, ASCE, 901-908.

[3] Friedler Eran and Alfiya Yuval (2010), "Physicochemical treatment of office and public buildings Greywater", water science and technology, 2357-2364

[4] Jokerst A.W., Roesner L. A., and Sharvelle S.E. (2009). "An Evaluation of Greywater Reuse Utilizing a Constructed Wetland Treatment System", Water Environment Research Federation sponsored report.

[5] Kariuki Francis W., Kotut Kiplagat and Ngángá Victor G. (2011) "The Potential of a Low Cost Technology for the Greywater Treatment", the Open Environmental Engineering Journal, 4, 32

[6] Kharwade A. M. and Khedikar Isha. P..,(2011) "Laboratory scale studies on domestic greywater through vermifilter and non-vermifilter", JERS/ Vol.II / Issue IV/October-December, 201, 35-39

[7] Kulabakoa N. R., Ssonkob N.K.M. and Kinobea J. (2011), "Greywater Characteristics and Reuse in Tower Gardens in Peri-Urban Areas - Experiences of Kawaala, Kampala, Uganda", The Open Environmental Engineering Journal, 4, 147-154

[8] Leal Hernandez L., Zeeman G., Temmink H. and Buisman C., (2007), "Characterization and biological treatment of greywater", Water Science \& Technology Vol 56 No 5, 193-200.

[9] Nesic Nevena and Jovanovic Ljubinko (2006), "Potential Use of Water Hyacinth (E. CRASSIPENS) for Wastewater Treatment in Serbia". USEPA 1988.
[10] Jasutkar (2010), “Greywater treatment by aerated constructed wetland", dissertation report. 